\title{
Histological Study Of The Effect Of Zinc Sulphate On The Toxicity Of Aluminium Sulphate In Liver And Kidney Of Male Albino Rats
}

\begin{abstract}
Azza M. Gawish
Department of zoology, Faculty of Science, Cairo University, Cairo, Egypt

Abstract

Aluminium (Al) is one of the most abundant and important elements in the environment. In recent years, the production of this metal and its toxicity increased with its discharge into the environment. This study was designed to evaluate the effect of $\mathrm{Al}$ intake toxicity in liver and kidney tissues of albino rats and the role of zinc as a protective agent against $\mathrm{Al}$ toxicity.

Fourty five male albino rats were divided into equal three groups. The first group of animals was considered as control. The animals in the second group were given $(50 \mathrm{mg} / \mathrm{kg} / \mathrm{day})$ of $\mathrm{Al}$ sulphate orally using gastric tube for 45 day. Third group were given Al sulphate $(50 \mathrm{mg} / \mathrm{kg} / \mathrm{day})$ followed by zinc sulphate $(50 \mathrm{mg} / \mathrm{kg} /$ day) orally as well as samples of liver and kidney tissues were obtained after 15, 30, 45 days of last doses respectively. Paraffin sections $(5 \mu \mathrm{m})$ were prepared for histological study stained with Haematoxylin \& Eosin.

The obtained histological results of the histological study of the second group showed that there were congested blood sinusoids and swelling of some hepatocytes within cytoplasm in which there were vacuoles, fragmented nuclei with some cellular infiltration. Kidney tissue showed shrinkage of some glomeruli and distortion of the tubular epithelial cells. Results in the third group, where zinc sulphate was added, showed amelioration and improvement in both liver and kidney tissues.
\end{abstract}

\section{Introduction}

Aluminium is one of the most abundant metal in the earth crust. Daily human exposure of $\mathrm{Al}$ ranges from 1.53 to $16 \mathrm{mg}$ /person/day (Domingo, 1995 and Jeffery et al., 1996). $\mathrm{Al}$ is present in water in the form of hydroxides, fluorides and sulphates (Hava et al., 1985, Goyer, 1996 and Alleva et al., 1998). Exposure to $\mathrm{Al}$ has recently been implicated in a number of human pathologies and symptoms of obstructive lung disease were recorded (Sjoren, 1988), samples of welders and many workers showed high deposition of $\mathrm{Al}$ salts in different tissues (Wennberg, 1998, Mur et al., 1998).

According to Massie et al., (1988); accumulation of $\mathrm{Al}$ has been found in liver and kidney but not in brain of mice given $\mathrm{Al}$ chloride (McDermott et al., 1979 and Markesbery et al., 1981). Weilhelm et al., (1996) declared that the lowest level of $\mathrm{Al}$ occurring in cytoplasm in the subcellular fractions might lead to accumulation of $\mathrm{Al}$ in the liver. Other study reported that moderate toxicity of $\mathrm{Al}$ compounds appeared in the hepatocytes when given in amounts near to pathological values (Muller et al., 1990). Van der Voet et al., (1992) reported that $\mathrm{Al}$ accumulation was correlated with the appearance of periportal giant cells due to $\mathrm{Al}$ administration in rabbits. Degeneration and some changes in the hepatic parenchyma were observed when male rats were given $\mathrm{Al}$ chloride (Ebina et al., 1984).

Bertholf et al., (1989) reported that high concentrations of $\mathrm{Al}$ caused necrosis and atrophy recorded in kidney tissue. Reduced renal functions were recorded in infants of human with high $\mathrm{Al}$ accumulations in their kidney tissue (Flaten et al., 1996). Light and electron microscopic studies were applied on kidney tissues in which swelling in some cells of the proximal renal tubules and distortion of renal cells of the kidney were observed due to $\mathrm{Al}$ administration (Spencer et al., 1995).

Recently, the toxic effects of aluminium has been correlated with induction of free 


\section{Azza M. Gawish}

radicals as has been demonstrated by ElDemerdash (2004) and Yossef (2004) who showed that $\mathrm{AlCl}_{3}$ significantly induced free radicals (thiobarbituric acid-reactive substances) and decreased the activity of glutathione S-transferase (GST) and the levels of sulphydryl groups ( $\mathrm{SH}$ groups) in plasma, liver, brain, testes and kidney of rat and rabbit, respectively.

Zinc, a potent antioxidant, which protects many body systems as liver kidney, brain and testes against free radicals ((Hafiez et al., 1989 \& 1990, Mansour et al. 1989, Liu \& Stemmer (1990a,b), Oteiza et al. (1996), Noh \& Koo (2001), and Ozkan et al. (2004). Liang et al., (1999) declared that zinc enter gastrointestinal tract as a compound of metallothionine secreted by salivary gland.

Zinc administration affects the $\mathrm{Al}$ accumulation in brain hippocampus and liver (Liang et al., 1999). Zinc supplementation may vary the effect of other metals as copper, Al in which Mendez-Alvarez et al., 2002 recorded that zinc alter the toxicological effect of $\mathrm{Al}$.

\section{Material \& Methods}

Fourty five adult male albino rats weighing 160-170 were supplied by the breeding unit of Holding Company for Biological Product \&Vaccines (VACSERA) and feed a diet and free access of tap water and kept under standard experimental conditions.

\section{Chemicals}

Chemicals used were $\mathrm{Al}$ sulphate $\left(\mathrm{Al}_{2}\right.$ (SO4) 3. $15 \mathrm{H} 2 \mathrm{O})$ and zinc sulphate $\left(\mathrm{ZnSO}_{4}\right.$. $7 \mathrm{H} 2 \mathrm{O}$ ); both were supplied as white powder soluble in water. Aluminium sulfate and zinc sulfate were products of Sigma Co., USA. The calculated dose of $\mathrm{Al}$ sulphate $(50 \mathrm{mg}$ $/ \mathrm{kg} /$ day) was recorded according to (Domingo J. L. 1995) and Zinc sulphate $(50 \mathrm{mg} / \mathrm{kg} /$ day) according to (Fortes et al., 1997).

Animal groups and experimental design:

The animals were divided into 3 equal groups, each of 15 rats: Group (1) control group.
Group (2): Animals of this group treated with $(50 \mathrm{mg} / \mathrm{kg} /$ day) of $\mathrm{Al}$ sulphate orally using gastric tube foe 45-day daily. Group (3): animals treated with $\mathrm{Al}$ sulphate $(50 \mathrm{mg} / \mathrm{kg} / \mathrm{day})$ followed by dose of zinc sulphate $(50 \mathrm{mg} / \mathrm{kg} /$ day) an hour later.

Rats of each group were sacrificed at 15,30 , and 45 periods. Samples of liver and kidney were fixed in aqueous Bouin solution for histological studies. $6 \mu \mathrm{m}$ thickness paraffin sections were prepared and stained with Ehrlich Haematoxylin \& Eosin according to (Bancroft \& Gamble, 2002)

\section{Results \\ Histological results: 1- Liver Control liver:}

Light microscope examinations of the control liver tissue showed that hepatic lobules extended in strands radiating from the central vein. These hepatic strands are separated from each other by blood sinusoids lined with endothelial cells (fig 1).

\section{Al sulphate treated group:}

The liver tissues of these animal group recorded mild histological changes, after 15 days of daily administration of with $\mathrm{Al}$ sulphate and some swollen cells and empty area appeared around the nucleus (fig 2); at 30 day interval inflammatory cell and some fragmentation of chromatin materials were appeared (fig 3). At the end of the experiment (45 day) empty spaces within the cytoplasm and dense bodies within the nuclei were appeared compared to the control group (fig 4).

\section{Al suphate - zinc sulphate treated group:}

Zinc sulphate supplementation after $\mathrm{Al}$ sulphate showed some improvement in liver tissue in which hepatocytes appeared almost and enlarged blood sinusoids normal at 15 day of treatment compared to $\mathrm{Al}$ treated group (fig 5). The cytoplasm was densely stai ned and little fragments were observed (fig 6 ). At the end of the experiment liver tissue was distorted with necrotic nuclei and zinc cannot induce clear effect in liver (fig 7). 


\section{II- Kidney Control kidney}

Control section of kidney of albino rats showed renal corpuscles, Bowman s capsule and renal tubules with their cuboidal cell lining. (Fig 8).

\section{Aluminium sulphate treated group:}

The kidney of the animals treated with Al sulphate showed various histological changes where slight shrinkage in the corpuscles were appeared within 15 day of treatment (Fig 9), At 30 day of administration the congestion of renal corpuscles were increased continuously (Fig 10), and renal tubules cells loosed their normal shape indicating distortion in their structures at 45 day of administration (Fig 11).

\section{Aluminium sulphate - zinc sulphate treated group}

Administration of $\mathrm{Al}$ sulphate followed by supplementation of zinc sulphate showed beginning of amelioration of kidney tissue at 15 day of treatment (Fig 12), continued with the effect of zinc, at 30 day of treatment less shrinked corpuscle was observed (Fig 13); but at the end of experiment (45day) the effect of $\mathrm{Al}$ was still affected the renal tubules and corpuscles in which zinc cannot appear improvement on kidney tissue (Fig 14).

\section{List of figures}

Fig (1): photomicrograph of liver section of control group showing normal liver cells and hepatic sinusoids $400 \mathrm{X}$.

Fig (2): photomicrograph of liver section of animal daily treated with $\mathrm{Al}$ sulphate for 15 day showing some granules within the cells with some vacuoles (arrow) and enlarged nuclei (400X).

Fig (3): photomicrograph of liver section of animal daily treated with $\mathrm{Al}$ sulphate for 30 days undefined cell membrane and granulated cytop-lasm (arrow) and dense chromatin materials were observed (400X).

Fig (4): photomicrograph of liver section of animal daily treated with Al sulphate for 45 day showing degenerated cells (400X).
Fig (5): photomicrograph of liver section of animal daily treated with $\mathrm{Al}$ sulphate followed by zinc sulphate for 15 day showing nearly normal appearance of hepatic cells $(400 \mathrm{X})$.

Fig (6): photomicrograph of liver section of animal daily treated with $\mathrm{Al}$ sulphate followed by zinc sulphate for 30 day revealed congestion in hepatic sinusoids and large empty spaces within the cells and few fragments inside the nuclei (400).

Fig (7): photomicrograph of liver section of animal daily treated with Al sulphate followed by zinc sulphate for 45 day showed dark dense chromatin bodies and undefined to the outer border of the cells (400).

Fig (8): photomicrograph of kidney section of control group showing normal kidney tissue and normal renal corpuscles (400X).

Fig (9): photomicrograph of kidney section of animal treated with $\mathrm{Al}$ sulphate for 15 day showing nearly normal kidney and some swollen glomerulus (400X).

Fig (10): photomicrograph of kidney section of animal treated with $\mathrm{Al}$ sulphate for 30 days showed shrinkage in the corpuscles with some infiltra-tion of lymphocytes (400X).

Fig (11): photomicrograph of kidney section of animal treated with $\mathrm{Al}$ sulphate for 45 days showed congested renal corpuscle and dead cells nuclei (400X).

Fig (12): Photomicrograph of a kidney section of animal treated daily with aluminium sulphate and supplem-ented with zinc sulfate for 15 successive days showing nearly normal appearance of the glomerulus and the tubule cells (400X).

Fig (13): Photomicrograph of a kidney section of animal treated daily with aluminium sulphate and supplem-ented with zinc sulfate for 30 successive days showing some ameliorating effect of zinc on corpuscle and renal tubules (400X).

Fig (14): Photomicrograph of a kidney section of animal treated with aluminium sulphate and supplem-ented with zinc sulphate for 45 successive days showed little effect of zinc on the toxicity of $\mathrm{Al}$ on kidney tissue (400X). 
Azza M. Gawish

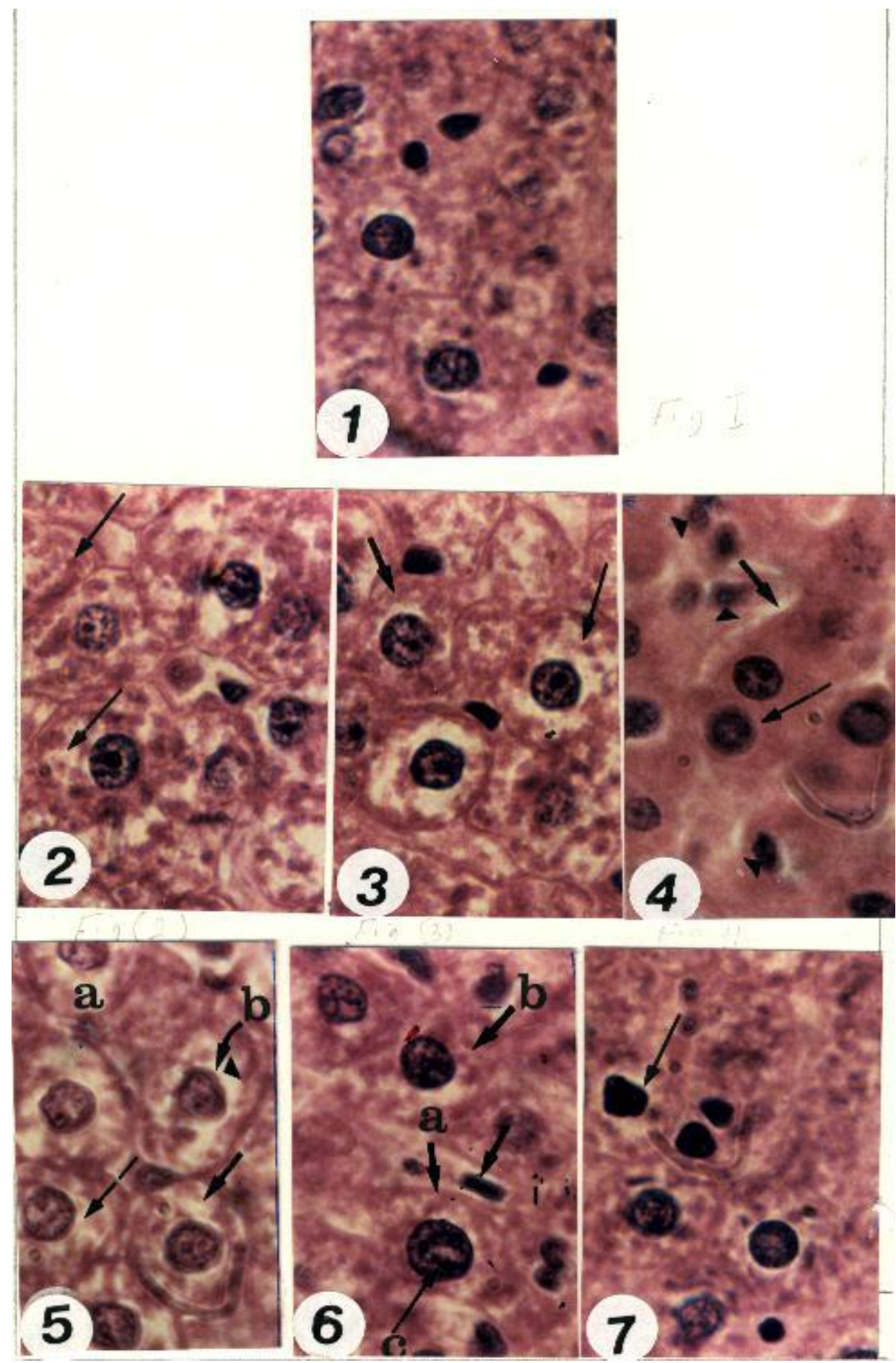


Histological Study Of The Effect Of Zinc Sulp........

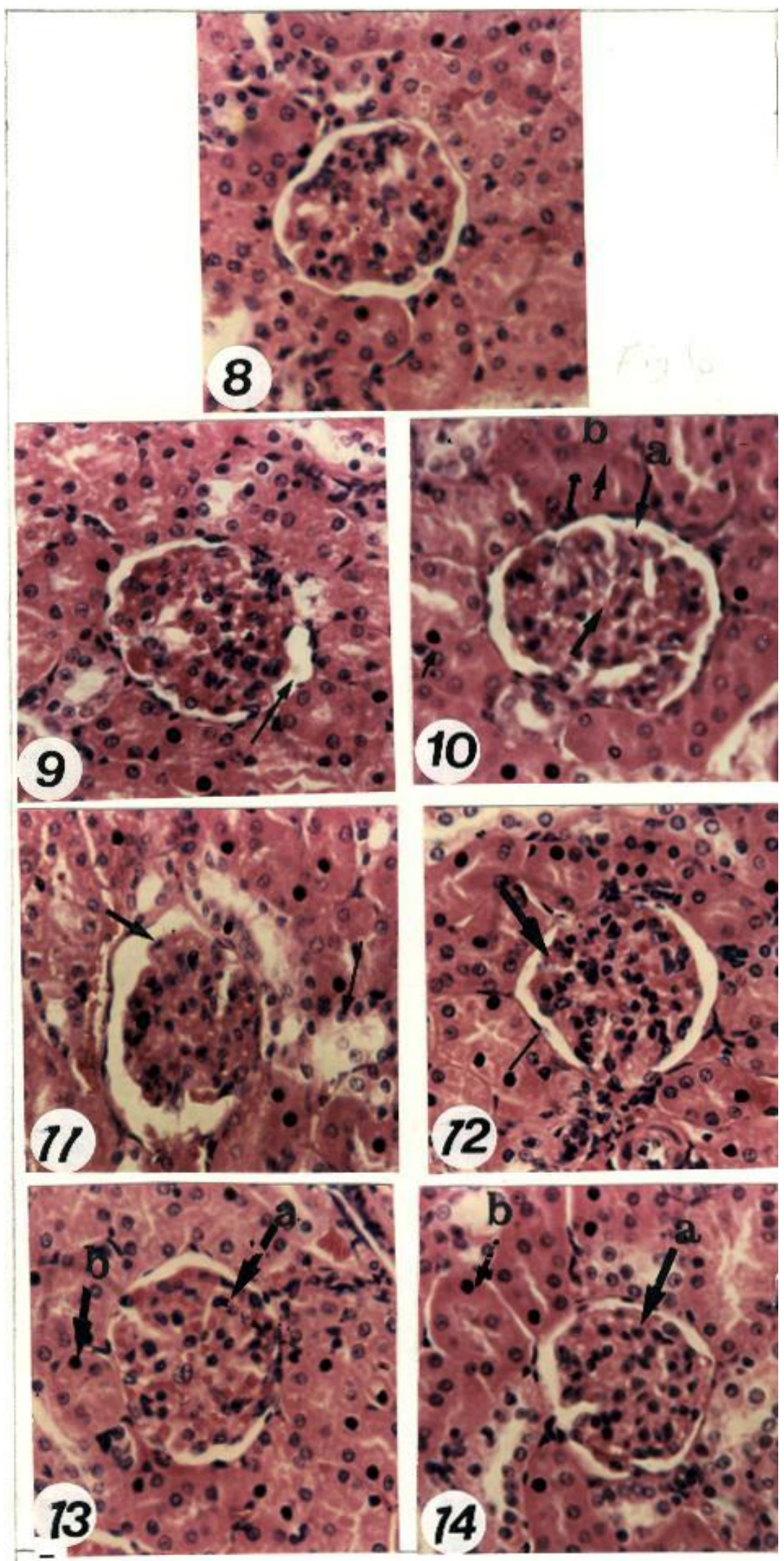




\section{Azza M. Gawish}

\section{Discussion}

Aluminium is one of the most abundant metal in the earth crust. $\mathrm{Al}$ is present in water as many complexes hydroxides, fluorides and sulphates (Goyer, 1996 and Alleva et al., 1998). Exposure to $\mathrm{Al}$ has recently been implicated in a number of human pathologies and symptoms of obstructive lung disease were recorded (Sjoren et al., 1989), tissuesamples of welders and many workers showed high deposition of $\mathrm{Al}$ salts (Mur et al., 1998). According to Massie et al., (1988); accumulation of $\mathrm{Al}$ has been found in liver and kidney of mice given $\mathrm{Al}$ chloride (McDermott et al., 1979 and Markesbery et al., 1981). Zinc is a potent antioxidant, is known to play a special role in protecting the tissues as liver, kidney, brain and testis against free radicals (Hafiez et al., 1989 \& 1990, Mansour et al. 1989, Liu \& Stemmer (1990a,b), Oteiza et al. (1996), Noh \& Koo (2001), and Ozkan et al. (2004). This study aimed to evaluate that if zinc supplementation after any exposure to $\mathrm{Al}$ salts as sulphate can deduce the toxic effect of $\mathrm{Al}$ on liver -kidney line of rats.

The results indicated that on liver tissue daily treated of with $\mathrm{Al}$ sulphate, showed some swollen cells with vacuoles around the nucleus and some fragmentation of chromatin materials were appeared. Empty spaces within the cytoplasm and dense bodies within the nuclei were appeared. Zinc sulphate supplementation after $\mathrm{Al}$ sulphate showed some improvement in liver tissue in which hepatocytes appeared almost and enlarged blood sinusoids. At the end of the experiment liver tissue was distorted with necrotic nuclei and zinc cannot induce clear effect in liver. Kidney tissue showed slight shrinkage in the corpuscles, and renal tubules cells loosed their normal shape due to administration with $\mathrm{Al}$ sulphate. Zinc improved beginning of amelioration of kidney tissue, but at the end of experiment (45day) the effect of $\mathrm{Al}$ was still affected the renal tubules and corpuscles.
From the results, we can conclude that the effect of $\mathrm{Al}$ is back may be to the accumulated $\mathrm{Al}$ in the different tissue and kidney can not able to excrete these $\mathrm{Al}$ leading to aggregation in he liver tissue, Some authors agree with this opinion as Massie et al., (1988); Weilhelm et al., (1996), declared that the lowest level of $\mathrm{Al}$ occurring in cytoplasm in the subcellular fractions which leading to accumulation of $\mathrm{Al}$ in the liver. Van der Voet et al., (1992) reported that $\mathrm{Al}$ accumulation was correlated with the appearance of periportal giant cells in the liver tissue. Bertholf et al., (1989) and Flaten et al., (1996), Mahieu \& Calvo, (1998) and McNall \&Fosmir, (1996) reported that high concentrations of $\mathrm{Al}$ caused necrosis and atrophy recorded in kidney tissue. Reduced renal functions recorded in infants with high $\mathrm{Al}$ accumulations in their kidney tissue. Other author backed the effect of $\mathrm{Al}$ to the induction of free radicals as demonstrated by (El-Demerdash, 2004 and Yossef, 2004). Zinc administration affects the $\mathrm{Al}$ accumulation in brain hippocampus and liver (Liang et al., 1999) and may vary the effect of other metals as copper, $\mathrm{Al}$ in which Mendez-Alvarez et al., 2002 recorded that zinc alter the toxicological effect of $\mathrm{Al}$ and also zinc acts as antioxidant reduce the effect of free radicals produced due to Al toxicity. (Hafiez et al., 1989 \& 1990, Mansour et al. 1989, Liu \& Stemmer 1990(a,b), Oteiza et al. 1996; Noh \& Koo 2001; and Ozkan et al. 2004).

\section{References}

1. Abreo K.; Jangula J.; Jain S.K.; Sella M. and Glass J. (1991): Aluminium uptake and toxicity in cultured mouse hepatocytes. J. Am. Soc. Nephrol., 1 (12): 1299 - 304.

2. Alleva, E.; Rankin, J. and Santucci, D. (1998): Neurobehavioral alterations in rodents following developmental exposure to aluminium. Toxicol. Ind. Health, 14 (1-2): $209-221$. 
3. Bertholf R.L.; Herman M.M.; Savory J. Carpenter R. M.; and Wills M.R. (1989): A long-term intravenous model of aluminium maltol in rabbits: tissue distribution, hepatic, renal, and cytoskeletal changes associated with systemic exposure. Toxicol. Appl. Pharmacol., 98 (1): $58-74$.

4. Dlugaszek M., Fiejka M.A., Graczyk A. Aleksadrowiez J.C. and Slowikow (2000): Effects of various aluminium compounds given orally to mice tissue distribution and tissue concentration of essential elements. Pharmacol. Toxicol., 86 (3): 135 - 9.

5. Domingo J. L. (1995): Reproductive and Developmental toxicity of aluminium: A review Neuro. Teratol., 17 (4): 515-521.

6. Drury R and Wallington E., (1980): Carlton's histological techniques. Oxford University Press, New York, $5^{\text {th }}$ edition. P. 138, $237 \&$ 241.

7. Ebina Y.; Okada S.; Hamaki S. and Midorikawa O., (1984): Liver, kidney, and central nervous system effect due to aluminium given intraperitoneally to rats: a multiple - dose subchronic study using aluminium nitroacetate. Toxicol. Appl. Phaemacol., 75(2): $211-8$.

8. El-Demerdash F.M. (2004): Antioxidant effect of vitamin $\mathrm{E}$ and selenium on lipid peroxidation, enzyme activities and biochemical parameters in rats exposed to aluminium. J Trace Elem Med Biol. 18(1):113-21.

9. Flaten T.P., Alfrey A.G., Birchall J.D., Savory J. and Yokel R. A. (1996): Status and future concerns of clinical and environmental aluminium toxicology $\mathrm{J}$. Toxicol. Environ. Health, 30 (6): 527-41.

10. Fortes, C; Agabiti, N.; Fano, V.; Pacifici, R.; Forastiere, F.; Virgili, F. and Zuccaro, P. (1997): Zinc supplementation and plasma lipid peroxides in an elderly population. Eur. J. Clin. Nutr., 51 (2): 97-101.

11. Goyer A.A. (1996): Basic Science of Poisons. In Toxicology Cassaret \& Doult 5th Eds. New York. Toronto London.

12. Hafiez, A, A, El-Kirdassy, Z.H., El-Malkh, N.M. and El-Zayat, E.M. (1990): Role of zinc in regulating the testicular function. Part 3. Histopathological changes induced by dietary zinc deficiency in testes of male albino rats. Nahrung. 34(1): 65-73.

13. Hafiez, A.A., El-Kirdassy, Z.H., Mansour, M.M., Sharada, H.M. and El-Zayat, E.M..
(1989): Role of zinc in regulating the testicular function. Part 1. Effect of dietary zinc deficiency on serum levels of gonadotropins, prolactin and testosterone in male albino rats. Nahrung. 33(10): 935-40.

14. Jeffery E. H; Abreo K.; Burgess E. Canata J and Greger J. L. (1996): Systemic aluminium toxicity effects on bone, hematopoietic tissue, and kidney. J. Toxicol. Environ. Health, 48 (6): 649-65.

15. Jones D. I. and Kochian L.V. (1997): Aluminium interaction with plasma membrane lipids and enzymatic metal binding sites and its potential role of aluminium toxicity. FEBS Lett., 400 (1): 1 - 57.

16. Liang J.Y; Liu Y.Y.; Zou J.; Franklein R. B.; Castello L.c. and Feng P. (1999): Inhibitory effect of zinc on human prostatic carcinoma cell growth. Prostrate, 40(3): 200 $-207$.

17. Liu, J.Y. and Stemmer, K.L. (1990a): Interaction of aluminum with zinc and copper and its effects on pituitary-testicular axis: a histological study. Biomed Environ Sci. 3(1):1-10.

18. Liu, J.Y. and Stemmer, K.L. (1990b): Interaction between aluminum and zinc or copper and its effects on the pituitarytesticular axis. II. Testicular enzyme and serum gonadotropin assay. Biomed Environ Sci. 3(1): 11-9.

19. Mahieu S. and Calvo M.L. (1998): Effect of chronic poisoning with aluminium on the renal handling of phosphate in rat. Toxicol. Lett., 94 (1): 47-56.

20. Mansour, M.M., Hafiez, A.A., El-Kirdassy, Z.H., El-Malkh, M.N., Halawa, F.A. and El-Zayat, E.M. (1989): Role of zinc in regulating the testicular function. Part 2. Effect of dietary zinc deficiency on gonadotropins, prolactin and testosterone levels as well as 3 beta-hydroxysteroid dehydrogenase activity in testes of male albino rats. Nahrung. 33(10): 941-7.

21. Markesbery, W. R.; Ehmann, W. D.; Hossain, T. I. M.; Alauddin, M.; and Goodin, D. T. (1981): Instrumental neuroactivation analysis of brain aluminium in Alzheimer's disease and aging. Ann. of Neuro. 10: 511-516.

22. Massie, H. R.; Aiello, V. R. and Tuttle, R. S. (1988): Aluminium in the organs and diet of aging C57BI16J mice. Mechan. of age. and Develop, 45: 145-156. 


\section{Azza M. Gawish}

23. McDermott, J. R.; Smith, A. I.; Iqbal, K. and Wisniewski, H. M. (1979): Brain aluminium in aging and Alzheimer's disease. Neurology, 29: 809-814.

24. McNall A.D. and Fosmire G.J. (1996): Zinc status does not affect aluminium deposition in tissues of rats. Biol. Trace. Elem. Rec., 53 (1): 7-18.

25. Mendez-Alvarez E, Soto-Otero R, Hermida-Ameijeiras A. and Lopez-Real A.M (2002): Effects of aluminium and zinc on the oxidative stress caused by 6hydroxydopamine autoxidation: relevance for the pathogenesis of Parkinson disease. Biochem. Biophys. Acta, 1586 (2): 155 - 68.

26. Muller G.; Bernuzzi, V.; Desor D; Hutin M.F.; Burnel D; and Lehr P.R. (1990): Developmental alteration in off springs of female rats orally intoxicated by aluminium acetate at different gestation periods. Teratology, 42 (2): 253-263.

27. Mur J.M.; Wild P.; Rapp R.; Vautrin J. P. and Coulon J.P. (1998): Demographic evaluation of the fertility of aluminium industry workers: influence of exposure to heat and static magnetic field. Hum. Reprod., 3 (7): 2016-2019.

28. Noh, S.K. and Koo, S.I. (2001): Feeding of a low-zinc diet lowers the tissue concentrations of alpha-tocopherol in adult rats. Biol Trace Elem Res. 81(2): 153-68.

29. Oteiza, P. L.; Olin, K. L.; Frage, C. G. and Keen, C. L. (1996): Oxidant defense systems in testes from zinc deficient rates. Proc. Soc. Exp. Biol. Med., 213: 85-91.
30. Ozkan, K.U., Boran, C., Kilinc, M., Garipardic, M. and Kurutas, E.B. (2004): The effect of zinc aspartate pretreatment on ischemia-reperfusion injury and early changes of blood and tissue antioxidant enzyme activities after unilateral testicular torsiondetorsion. J Pediatr Surg. 39(1): 91-5.

31. Sjoren, B.; Elinder, V. G. and Lidums, V. (1988): Uptake and urinary excretion of aluminium among welders. Intern. Arch. of Occup. and Environ. Health, 60: 77- 79.

32. Spencer A. J.; Wood J.A; Saunder H.C.; Freeman M.S. and lote C.J. (1995): Aluminium deposition in liver and kidney following acute intravenous administration of aluminum chloride or citrate in conscious rats. Hum. Exp. Toxicol., 14 (10): 787-794.

33. Van der Voet G.B., Brandsma A.E., Heijink E. and Wolff F.A. (1992): Accumulation of aluminium in rat liver: association with constituents of the cytosol. Pharmacol. Toxicol. 70 (3): 173-6.

34. Wennberg A. (1998): Effects on the nervous system among welders exposed to aluminum and manganese. Occup. Environ. Med., 53 (1): 32-40.

35. Wilhelm M.; Jaeger D.E.; Schull; Cablitz, H.D.; Hofner D. and Idel. H. (1996): Hepatic clearance and retention of aluminium: studies in the isolated perfuse rat liver. Toxicol. Lett., 31(3): 257-63.

36. Yousef M.I. (2004): Aluminium-induced changes in hemato-biochemical parameters, lipid peroxidation and enzyme activities of rabbits: protective role of ascorbic acid. Toxicology, 199 (1): 47-57. 


\title{
دراسات هستولوجية عن تأثير كبريتات الزنك على سمية كبريتات الألومونيوم

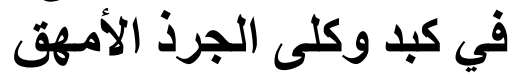

\author{
عزة محمود جاويش \\ قسم علم الحيو ان ـ كلية العلوم - جامعة القانئ
}

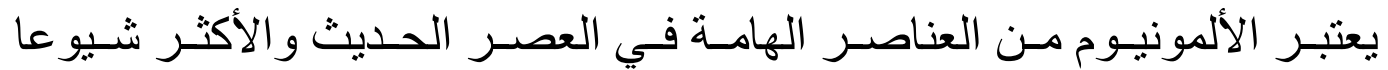

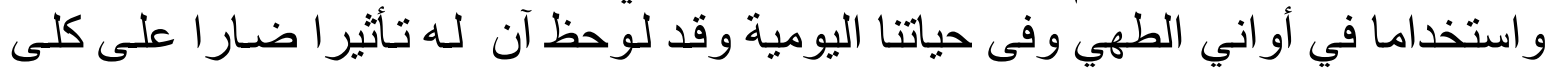

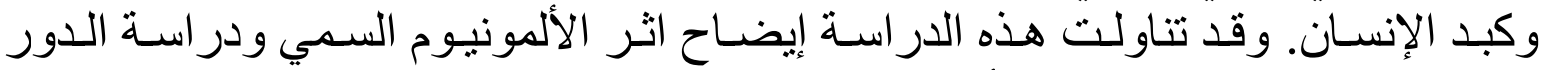

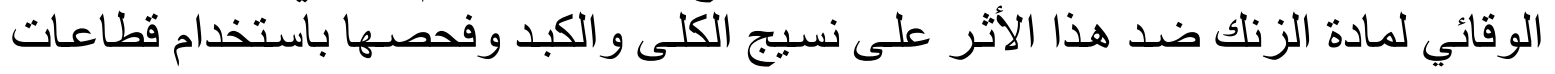

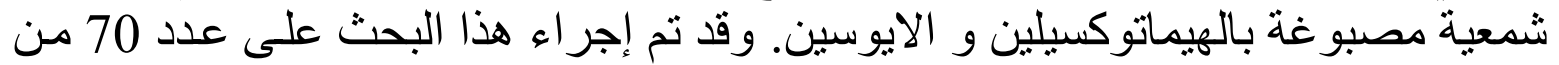

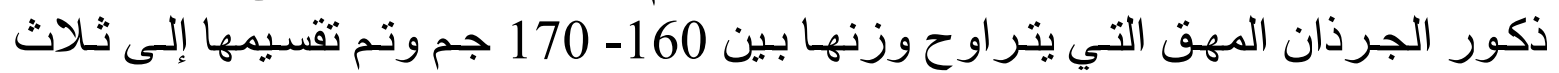

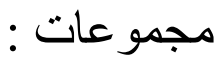
المجمو عة الأولى تعتبر مجمو عة ضابطة و المجمو عة الثانبة تعاطت جر عات من كبريتات

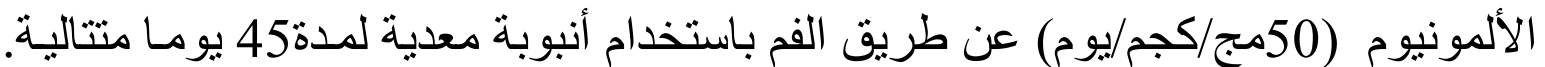

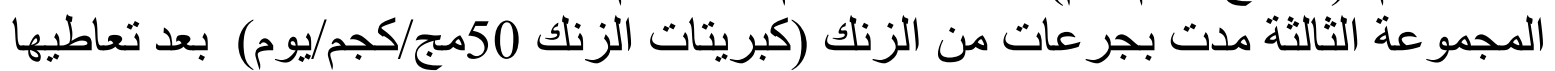

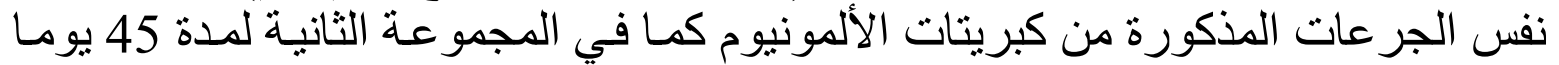
أيضا.

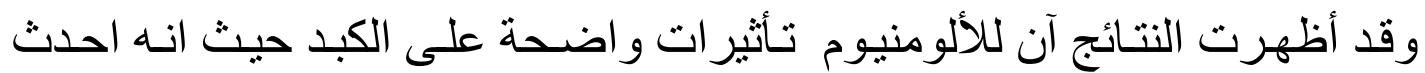

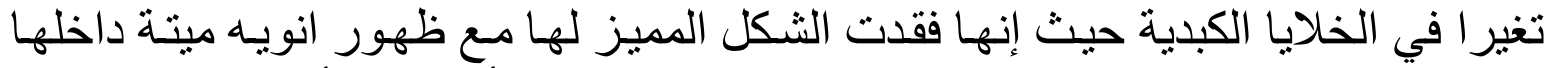

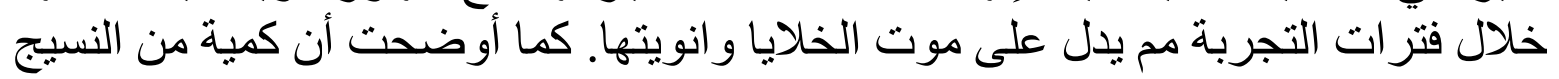

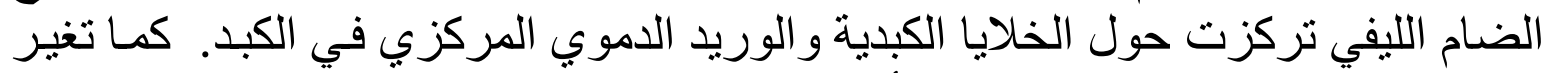

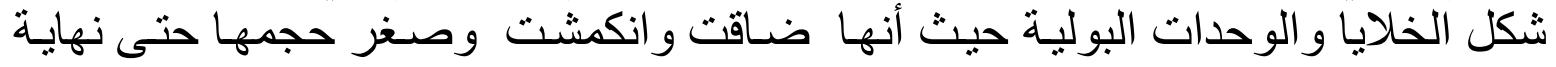

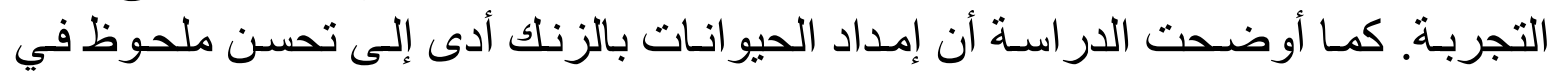

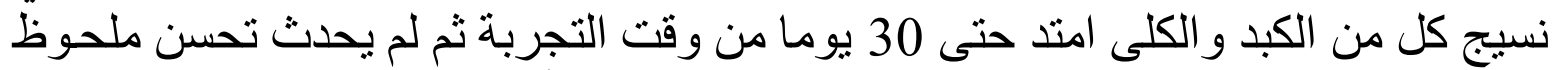

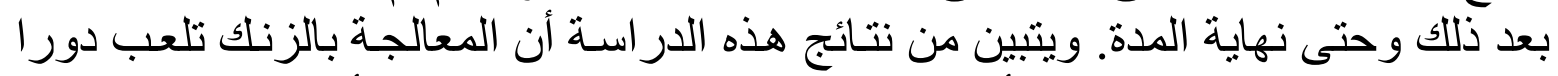

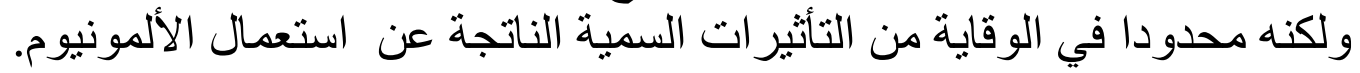

